Recent applications published by the International Commission on Zoological Nomenclature in the Bulletin of Zoological Nomenclature (volume 42, part 4, 6 December 1985) included the following:

Semionotus Agassiz, 1832 (Osteichthyes)

Cheirurus Beyrich, 1845 (Trilobita)

Recent Opinions published in the same issue of the Bulletin included the following:

Opinion 1355 (p. 332). - Lingula anatina Lamarck, 1801 (Brachiopoda) is the type species of Lingula Bruguiere (1797). The Commission would welcome comments and advice on the applications, if possible within six months. The Commission's address is:

P. K. Tubbs, Esq., Executive Secretary

International Commission on Zoological Nomenclature

$\%$ British Museum (Natural History)

Cromwell Road, London SW7 5BD, England

\title{
ANNOUNCEMENT
}

\section{PALAEONTOGRAPHICAL SOCIETY BROCHURE}

The Palaeontographical Society has produced a brochure listing all available parts with current prices. As a result of a recent stock-take, a number of rare parts are now available but in very short supply. A copy of the brochure and order form is available on request from S. P. Tunnicliff, Secretary, Palaeontographical Society, \% British Geological Survey, Keyworth, Nottingham NG12 5GG, England. 